\title{
An Overview of Indonesian Renewable Energy Studies and Its Investment Opportunities
}

\author{
Alfred Boediman ${ }^{1}$, Raden A. Rahadi ${ }^{2}$, Bagus A. Nugraha ${ }^{2, *}$ \\ ${ }^{1}$ The University of Chicago Booth School of Business, Hong Kong, \\ 168 Victoria Rd, Mount Davis, Hong Kong \\ ${ }^{2}$ School of Business and Management, Institut Teknologi Bandung \\ Jl. Ganesa No.10, Lb. Siliwangi, Kecamatan Coblong, Kota Bandung, Jawa Barat 40132, Indonesia
}

Received 29 July 2021; Accepted 22 August 2021

Available online 31 August 2021

\begin{abstract}
By conducting a synthesis review of recent literature, this study aims to provide a comprehensive conceptual model for acknowledging factors determining private investment in the renewable energy sector within an emerging country, Indonesia. The synthesis and thus guides stakeholders to encourage investment from the private sector in renewable energy development. From this study, the authors summarized all factors studied arguably influential in affecting the private sector to invest as a source of development funding and presenting several key indicators of renewable energy investment opportunities in Indonesia. The factors that influence the development of the energy sector include policies related to human capital, environmental protection and energy efficiency. Therefore, this study should serve as the baseline for future advanced studies.
\end{abstract}

Keywords: renewable energy, investment opportunities, emerging country, Indonesia

\section{Introduction}

Not only well known as an archipelagic country with more than 17,500 islands and a total coastal line of $95,181 \mathrm{~km}$, but Indonesia is also notably known for its abundant energy resources (Maulidia et al., 2019). Indicated by coal, natural gas and geothermal availability, numerous scholars agreed that Indonesia is arguably one of the richest countries compared to others in energy resources, within the soil or/and the surface (Udin, 2020). Extending this identity to the potential growth in the economy, population, higher standard of living and rapid urbanization soon, thus a question arises; with all current energy supply which dominated by non-renewable energy, will Indonesia's energy and power availability go after the demand in which expected to be higher and continuously increase in the future? To answer the question, the Indonesian government has started the energy sector reformation from reliance on fossil fuels and start to utilize more renewable energy, step by step, from the late ' $90 \mathrm{~s}$ (Bappenas, 2012). Furthermore, in the form of commitment, specialized boards of organization and policies, the Indonesian government has evolved in managing the energy sector.

Conducting energy sector reformation in Indonesia as an emerging country with an unstable economy, high population and geographical challenges requires tremendous efforts, intricate policy and firm regulations, well-coordinated work among related stakeholders and predominantly a huge amount of investment funds. Thus, the government cannot face all of these challenges without external support. Therefore, research and insight from scholars and investment funds from private sectors are indisputably imperative to support the government's effort in renewable energy development in Indonesia, which has enormous potential.

Referring to the current condition, the utilization of renewable energy is debatably still too low from its targets sets by the stakeholders, even after decades of development. Currently, it has only reached $6.51 \%$

\footnotetext{
* Corresponding author

E-mail address: bagus-aditya@sbm-itb.ac.id
} 
in 2016, with a 23\% target of the energy mix in 2025 for renewable energy generation (Winarno et al., 2016). According to prior literature, underinvestment in electricity infrastructure, including generating renewable energy sourced problem in Indonesia, is believed to be the main issue causing Indonesia's struggles to reduce the amount of fossil fuel imports and have several challenges attached in realizing the plan of renewable energy utilization (Sovacool \& Mukherjee, 2011). Maulidia et al. (2019) argued that the reasons why Indonesia energy sector has been underinvested by the private sector, due to the government's neglect of private sectors within policy-making and inability to understand comprehensively those factors needed to encourage private sectors' investment particularly, and energy sector development in general.

These phenomena are captured by this current study and prompt the authors to conduct academic studies to fulfill the knowledge void on factors determining private investment in the energy sector and provide investment opportunities analysis for the private sector regarding renewable energy sector investment in Indonesia. Numerous scholars have been conducted deepen analysis about policies considered needs to be prioritized by the government in encouraging private sector investment (Dutu, 2016; Maulidia et al., 2019; Winarno et al., 2016), other non-financial factors that have an influence on energy sector development (Arafah et al., 2018; Udin, 2020), and even all types of renewable energy resources as a whole and its potential (Desfiandi et al., 2019; Hidayatno et al., 2019; Mustikaningsih et al., 2019; Putrasari et al., 2016; Setiartiti, 2018; Sharvini et al., 2018). Nevertheless, to the best of the authors' knowledge, no primary model has been proposed regarding all factors considered influential in encouraging private investment in the energy sector. Moreover, prudent investment opportunities analysis of renewable energy in Indonesia has not been identified from the available literature.

Based on the gap analysis, this study aims to provide a conceptual model that can guide policymakers and investors in developing a strategy for addressing the various challenges and opportunities within the renewable energy industry in Indonesia. Furthermore, it will support all related stakeholders to perform necessary actions to develop and achieve the renewable energy target in Indonesia. Most importantly, addressing investment opportunities in Indonesia's renewable energy.

\section{Literature Review}

\subsection{Indonesia - Energy Scenario}

This subsection presents the existing energy scenario of Indonesia and the current government plan in developing renewable energy and substantially discussing Indonesia's current renewable energy development and outlook for achieving the target.

Primary energy requirement and energy market - According to the Ministry of Energy and Mineral Resources in Asia Clean Energy Forum 2017, in the year 2025, Indonesia's total primary energy requirement amounted to 92.2 million tons of oil equivalent (Mtoe) (DJEBTKE, 2017). To achieve the requirement, power plant capacity is expected to reach $180 \mathrm{GW}$, where $45 \mathrm{GW}$ or $25 \%$ of the power capacity comes from new renewable energy. Referring to national energy policy, the hydro sector will dominate the NRW power plant capacity with $17.9 \mathrm{GW}$, followed by geothermal with $7.2 \mathrm{GW}$ and several renewable energy resources (Government's Regulation No. 79/2014). However, due to the growth prediction of customers in Indonesia and area development in Java-Bali and East Indonesia, the total amount of primary energy requirement is becoming variable. Therefore, it is expected to increase along the way to 238.8 Mtoe (Maulidia et al., 2019).

According to the Electricity Supply Business Plan (RUPTL) of Indonesia in 2016, Indonesia's electrification ratio was only $91.16 \%$ over $99.7 \%$ by 2025 's target. This percentage is relatively low compared to other ASEAN countries (WAVTEQ, 2017). There are 12,659 villages in Indonesia from electrification rate have not to access to electricity (data from the Ministry of Energy and Mineral Resources). Concerning that, the Indonesian Investment Coordinating Board of the Ministry of Investment (BKPM) stated, to increase the electrification rate and stimulate the growth of the energy sector in Indonesia, over USD 78 billion is required from private investment in the development of the 
Indonesian power sector (WAVTEQ, 2017). The statement coming from BKPM was suggested as well by The International Energy Agency (IEA) for Indonesia; 1) stop the least-efficient coal power plants utilization, 2) implement fossil fuel subsidies reform to end wasteful energy, and 3) pitch to encourage private sector investment in renewable energy (International Energy Agency, 2018).

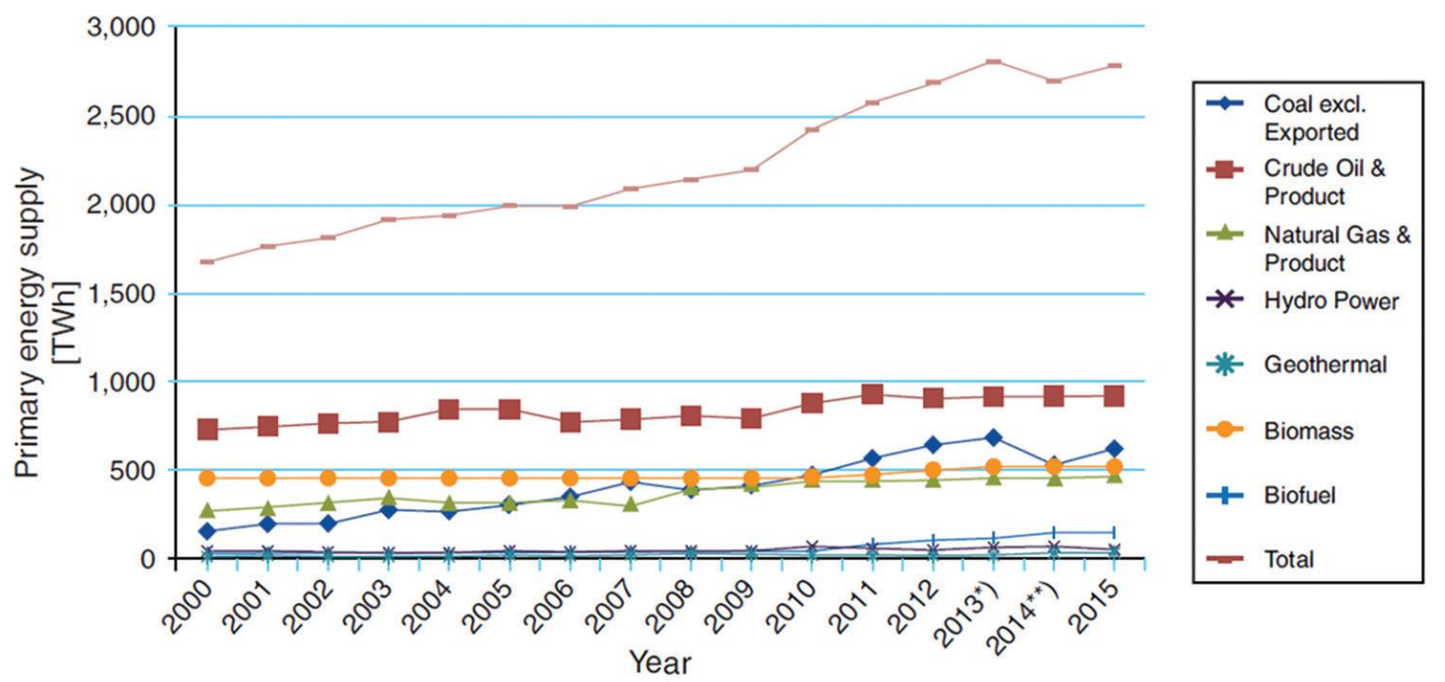

Figure 1. Primary energy supply in Indonesia (Pusdatin (2016) in Udin (2020).

Electricity generation - Rich in energy resources but poor in electricity (Maulidia et al., 2019). That is the irony faced by Indonesia. Retrieving data from the International Renewable Energy Agency (IREA), Indonesia has the potential to produce $716 \mathrm{GW}$ of energy from solar photovoltaic, hydropower, bioenergy, geothermal, ocean wave power and wind (Udin, 2020). However, in 2015, the electricity generation was still dominated by oil, coal and gas up to 93.8\% (Dutu, 2016; Tasri \& Susilawati, 2014). Between of 2011-2017, the Directorate General of New and Renewable Energy and Energy Conservation of the Ministry of Energy and Mineral Resources, Republic of Indonesia, has built over 600 power plants worth 3.01 trillion rupiahs across Indonesia national budget source of funding (DJEBTKE, 2017). Even though those new and renewable energy power plants are not dominated by the energy generator list and need huge investment for production and maintenance, the Ministry of Energy and Mineral Resources still shows optimism for Indonesia's renewable energy potential (Udin, 2020). Henceforth, in trying to maximize the potential, Indonesia must face numerous challenges in transition and implementation. Rapidly growing demand, aging oil fields, stagnant exploration and depleting oil and coal reserves are the challenges forcing Indonesia to formulate a new strategy for energy supply and security (Maulidia et al., 2019). A comprehensive strategy and applicable regulatory framework are required in guiding the transition to renewables smoothly.

Transition challenges - As mentioned, several labyrinthine challenges precipitated the Indonesian government to react further from current efforts. Not mean to factor out Indonesia's awful GHG emissions due to deforestation and fossil fuel burning, inadequate technologies and limited development research infrastructure. However, the inability to compensate for the underinvestment within the energy sector is the main issue affecting the performance for decades of transition. To conduct development and build new energy infrastructure, Indonesia needs to prepare many financial resources (Udin, 2020; Winarno et al., 2016).

On the other side of the coin, before the revision made in 2014 when the Indonesian government decided for the first time to produce a concrete policy regarding renewable energy reformation in the national energy policies in 2006, Indonesia did not have firm and achievable targets or any enabling policies. With specified targets on the line, even the ones appearing to be less realistic, all stakeholders in renewable energy sectors in Indonesia will have a purpose. Every action taken toward the target will eventually implicate the reduction of fossil fuel reliance levels. Moreover, a target of renewable energy utilization on the energy mix shows a good sign of the Indonesian government. Maulidia et al. (2019) 
stated that the government has considered renewable energy to solve electrification problems, energy supply and environmental issues.

Role of the private sector - Renewable energy projects with imported technologies and advanced human capital will always require a huge amount of funding (Naser, 2014). National budget or public sector funding will arguably be insufficient to finance the projects. Hence private investment, with all its finance and technology ability, plays a crucial role in Indonesia's renewable energy development. With all the opportunities for renewable energy resources, market size and potential growth, some global consulting firms, private equity and venture capital are agreed. They recommend that private sectors have a look at Indonesia's renewable energy sector. Not only limited to abundant renewable energy resources but the commitment shown by the Indonesian government towards a greener future. For instance, $20 \%$ target announcement for all locally manufactured vehicles to be electric vehicles by 2025 (Kejora Capital, 2021). In short, Indonesia has promising investment growth and imperative roles played by the private sector to address the underinvestment in renewable energy infrastructure. However, there are still reluctance by the private sector to enter the renewable energy business. Several key factors that are identified including the issue of regulation and policy, the lack of knowledge and awareness of the consumers and other stakeholders about the importance of renewable energy infrastructure, and lastly is the disarrayed communities as the linking hub and network to promote and educate the stakeholders.

\subsection{Previous Studies}

In the following subsection, this study will posit several synthesis reviews from previous studies discussing factors determining private investment in the energy sector and what it takes to help Indonesia in achieving the renewable energy target in 2025. The selected synthesized papers will help to explain and understand about the underlying reasons for private investment to enter and invest in renewable energy infrastructure.

\section{a) Policy Reformation}

Fundamentally, in developing renewable energy and its deployment, all stakeholders in Indonesia's energy sector must acknowledge the three important aspects of energy development: affordability, security and sustainability (Ardiansyah et al., 2012). In ensuring the aspect affordability and security, the Indonesian government needs to perform as great as the commitment for energy sector reformation. Through renewable energy, Indonesia can reduce its dependence on fossil fuels and improve its energy efficiency. To achieve renewable energy sustainability, the government needs to reform the policy (Maulidia et al., 2019). In addition, enabling policies are needed to mobilize the funding, improve the coordination among stakeholders, and facilitate technology and knowledge transfer (International Energy Agency, 2018). All these efforts are believed to help the government in tackling energy growing demand in Indonesia.

Practically, the fundamental or theory-based action always has its hurdles in the implementation process. Compared with cheap coal and biofuels, it is currently nothing but difficult to provide affordable, reliable and sustainable renewable energy in Indonesia (Ardiansyah et al., 2012). To ensure the acceleration of the deployment of smart grids and related infrastructure projects, which require huge investments, Indonesia's government needs to rely on private sector investment. Therefore, it is nearly implausible to expect private funding if Indonesia does not create an attractive policy that can be considered their risk and return profile (Schmidt et al., 2013). Since, playing the main role in achieving the renewable energy target is impossible without improving the policy and regulatory aspects.

Policy reformation in this matter has a huge spectrum. Concerning that, this current study has successfully summarized several prior studies that contributed to determining the spectrum; Maulidia et al. (2019), with a qualitative assessment of Indonesia's changing policy, suggested the reformation should be addressed to market reform, feed-in tariffs, restructured subsidies, unclear mandates, bureaucratic processes, accountability and limited institutional capacity. However, another researcher 
has a different point of view. National energy policies are made to guide a lower level of government. Thus, policy reformation should be detailed at the lower levels of government or at least the provincial level to guide all regional stakeholders, including private sectors (Winarno et al., 2016).

Dutu (2016) argued that the government should pay serious attention to clarifying, streamlining and publishing simple policies in energy as a part of the reform. Additionally, specific policies for revitalizing fossil fuel, environment protection, land rights, on-shore processing and removing foreignownership restrictions will be more attractive for private sectors and help bring much-needed investment (Dutu, 2016). On the other hand, to develop effectively, the government needs to provide a comprehensive and accurate database by proper and strict policy for those renewable energy potentials. Hence it is becoming a value-added for the private sector (Hesty et al., 2021).

Moreover, to tackling the inequality issue as well, Schmidt et al. (2013) suggested that government needs to reform the policy that can encourage the private sector to invest in geographically remote areas or hard to reach areas. Reforms include fossil fuel subsidy re-distribution and public de-risking measures (Schmidt et al., 2013).

Despite the underinvestment in the power sector, The Indonesian Power Company (Perusahaan Listrik Negara) still monopolizes the industry. The monopoly is creating another problem for the development of renewable energy sources in Indonesia. Some previous studies stated that the government needs to consider the policy to create a competitive wholesale market as an ideal situation (Setyawan, 2014). With policy reform, scholars believed it could improve the good governance practices in PLN, especially for PLN's renewable energy businesses. Differently, Tumiwa \& Rambitan (2013) suggested that policy reform should be focusing on scaling up public and private investment through fiscal incentives, renewable energy funds and temporary subsidies for renewable energy (Tumiwa \& Rambitan, 2013).

Deeper into micro scales such as urban areas, where the household sector plays an important role in the energy demand, a reform of renewable energy usage is proposed to help reach national electrification and environmental targets (Hariadi et al., 2018). Reformation on the policy should address clear responsibility and task allocation responsible for operation and maintenance costs and financial feasibility within projects conducted in rural areas (Hariadi et al., 2018).

Stakeholders can easily access the summary of renewable energy sourced electricity in Indonesia (Maulidia et al.,2019). In their summary, Marquardt (2014) suggested that policy reform should be conducted to specifically improve institutional capacity regarding the business doing in renewable energy development. Instances, improvement of quality of services and capacity development (Marquardt, 2014). Last but not least, the policy reform for this matter could be directed to help government institutions engage both private and state-owned enterprises to unlock the potential of private finance or indirectly connect those private investments towards other national investment projects (Nakhooda, 2014).

\section{b) Human Capital Development}

To attract private investment and to accelerate development, only conducting policy reform is considered inadequate. Udin (2020) suggested that to achieve renewable energy in 2025, human resource development is significantly needed to develop renewable energy in Indonesia. His opinion was supported by Mahmood et al. (2019), who argued that there is a significant relationship between renewable energy and human capital. Furthermore, Sharvini et al. (2018) researched Southeast Asian countries, energy and consumption are linked to human development. In the paper example, the researcher suggested that collaboration between Malaysia and Indonesia who shared the similar geographics and natural resources abundance can produce a positive impact in the welfare of the countries, leading to improved human capital development. Moreover, energy utilization is proven to increase human resources and operate and maintain renewable energy facilities or projects (Day et al., 2018). By improving the human capital development, in return, the perceptive and quality of life of the 
human capital will increase, leading to the higher knowledge and understanding about the importance of renewable energy infrastructure development. To conclude, human capital development will increase the utilization of renewable energy in Indonesia, particularly as well as increase the attractiveness of this sector for private investment (Dias et al., 2006; Singh, 2012).

\section{c) Empowered Communities}

The use of renewable energy in Indonesia will bring hurdles within the implementation. A commitment to empower communities needs to be done by the government in changing Indonesian habits in using fossil fuel energy to renewable energy (Arafah et al., 2018). Empowerment should be addressed to stimulate community-based initiatives, such as the IBEKA scheme-a community empowerment movement beyond supplying electricity from micro-hydro in Indonesia (Guerreiro \& Botetzagias, 2018; Tumiwa \& Rambitan, 2013). In their research, an intermediary organization like IBEKA in stimulating renewable energy development in Indonesia is crucial, particularly in building communities' ownership, improving Indonesia's technical, entrepreneurial and managerial capacities, to transfer knowledge and technologies. The IBEKA Foundation is a non-profit non-governmental organization whose business base is the development of people's living standards through the formation of an entrepreneurial spirit among the community and improvement of the economic system and infrastructure of micro hydro power plants (PLTMH), especially in remote areas in Indonesia. The main objective of IBEKA is the economic development of a community in a remote area by increasing the per capita income of these communities. In short, empowered communities could bridge internal and external factors and thus represent the attractiveness of the renewable energy sector in Indonesia towards private sectors.

\section{Conceptual Framework}

Based on the literature review on previous studies, three variables are considered factors determining private investment in the renewable energy sector and its development in achieving the target in Indonesia. Therefore, the conceptual framework can be acknowledged as in the following Figure 2 below. Understanding the factors that determine private investment in Indonesia's renewable energy sectors can help various stakeholders develop these sectors. Therefore, the unrealistic target may be achieved soon in the near future and declare that Indonesia no longer relies on fossil fuel energy $100 \%$.

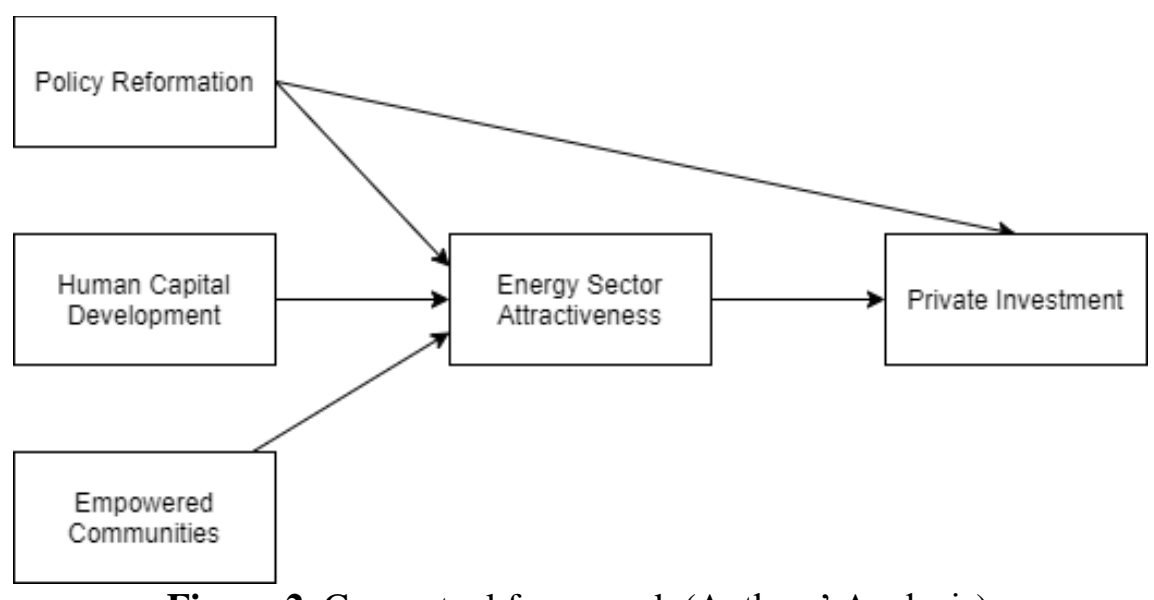

Figure 2. Conceptual framework (Authors' Analysis).

In brief, from the model we can see that in order to attract private investment to invest in renewable energy infrastructure, first it should have to have its own uniqueness and pull factors that differentiate themselves from the conventional energy infrastructure. Based on the literature synthesis, we can conclude that there are three major variables influencing it: policy reformation, human capital development and empowered communities. Improving the efficiency of the tax system, flexible regulation and other incentives can help boost the attractiveness of renewable energy. At the same time, it can influence the overall private placement sentiments in the country. Secondly, the human capital development in the country. By raising awareness about the danger and how obsolete the conventional 
energy infrastructure, more consumer and investors will change their lifestyle to embrace the renewable energy idea. Lastly, the empowered community acted as the trigger and network hub to propagate and spread the discourse about the importance and the benefit of renewable energy usage. As a new a foreign concept, there are risks presented in the development of renewable energy infrastructure. Constant education to improve the human capital development and empowering the communities are some of the surefire way to minimize and mitigate the risks presented here.

\section{Investment Opportunities}

This section focuses on assessing renewable energy investment opportunities in Indonesia by providing a key investment outlook and discussing each renewable energy sector, highlighting the demand, capacity and generation.

\subsection{Key Investment Outlook}

Indonesia in ASEAN — The 2021 GDP growth forecast for Southeast Asia is expected to be 4\%, a $0.4 \%$ cut from the previous forecast due to mobility restrictions reimposed to combat a COVID-19 resurgence across the region. Singapore is the only country in the region facing a bullish trend while the rest remain unchanged or downgraded. The GDP growth forecast for 2022 is expected to be $5.2 \%$ to reflect the expected increase in vaccination coverage (Asian Development Bank, 2021). As the largest economy in ASEAN, Indonesia's GDP is forecast to increase from US\$862 billion in 2015 to US\$2.2 trillion in 2025 (WAVTEQ, 2017). However, due to the pandemic, Indonesia's GDP growth forecast is reduced to $4.1 \%$ from the previous $4.5 \%$, mainly due to the second wave of infections (Asian Development Bank, 2021). From 2021 onwards, it is expected that the country will experience stable growth of around $5.21 \%$ to $5.81 \%$ (O'Neill, 2021). However, it is in its nature quite speculative, especially with the current pandemic.

Energy Sector - ASEAN has set an ambitious target to double its renewable energy portion to $23 \%$ of the region's total energy mix to generate electricity by 2025 and is expected to reach $31 \%$ by 2050 . They are adding approximately 35-40 GW of renewable energy by 2025 . Solar is currently highly regarded as the best alternative for renewable energy in the region (Kejora Capital, 2021). Indonesia produced 616 million tons of coal, 2.8 million standard cubic feet of natural gas and 272 million barrels of oil in 2019. Indonesia is a net energy exporter, and the energy sector and overall economy primarily rely on natural resource extraction, with coal as the principal export (11.2\% of total energy export value) and palm oil second (8.76\%) (Asian Development Bank, 2020). From the period 2010 to 2019, energy production declined by $20 \%$. Already a net importer of oil, Indonesia is predicted to be a net importer of natural gas by roughly 2030 (Agarwal et al., 2020). Primary energy demand has increased by $3 \%$ per year since 2010. Indonesia's Electricity Power Supply Business Plan (RUPTL) 2019-2028 estimated annual electricity demand increases by $6.4 \%$ through 2019-2028. The MEMR targets to increase renewable energy to $45 \mathrm{GW}$, an increase of $20 \mathrm{GW}$ from 2021. The increased target will make up to 23 percent of the total installed energy capacity for the country. In addressing the persisting electrification problem, the RUKN aims to achieve a 100\% electrification ratio nationwide by 2024 (MEMR, 2017). The government has supported these goals by providing both financial and fiscal incentives, the former being below the market loan interest rate and the latter, various tax allowances and exemptions. Moreover, the electrification goal is supported by revising the BOOT and tariff program to attract investments (DJEBTKE, 2017).

Foreign direct investment in Indonesia - FDI into Indonesia has increased by almost two times greater to nearly USD 30 billion a year from 2013 to 2016. According to official FDI data from BKPM, Greenfield FDI has seen a rapid increase from USD14.8 billion of announced FDI projects to nearly USD 40 billion in 2015 (Financial Times cited in TPSA, 2017). In the energy-related sectors, FDI in Indonesia amounts to over USD7 billion in 2013 and 2015 declining to USD 5 billion in 2016 (WAVTEQ, 2017). 


\subsection{Renewable Energy Indonesia}

\section{a. Solar Photovoltaic}

The solar energy power generation sector in Indonesia has been idle despite its immense potential. According to the RUPTL 2019-2028, Indonesia needs to increase solar capacity by approximately 758 MW to achieve its 908 MW target in 2028 (Asian Development Bank, 2020). Moreover, RUEN targets to increase solar PV capacity to $6,500 \mathrm{MW}$ by the end of 2025 , which gives the need to fast-track the development given that the country is only at roughly 152 MW capacity, or $27.6 \%$ from 2019 target, $550 \mathrm{MW}$ (IESR, 2019). To achieve these ambitious solar targets in 2025, USD 3,755 million of total investment was estimated by BKPM from 2015-2025, the investment was addressed to reach the capacity and generation target of solar PV. Details in regard to BKPM estimation will be expressed within the Table 1 below.

Table 1. Solar photovoltaic capacity and electricity generation target, Indonesia, 2015-2025 (BKPM, 2016).

\begin{tabular}{lrrr}
\hline Year & 2015 & 2020 & 2025 \\
\hline Investment (Million USD) & 834 & 1,140 & 1,781 \\
\hline Capacity (MW) & 417 & 760 & 1,425 \\
\hline Generation (GW) & 2,922 & 5,326 & 9,986 \\
\hline
\end{tabular}

Nevertheless, to produce sufficient enabling conditions in which fostering the private investment, the government committed to be more open and willing to provide a great investment climate in Indonesia renewable energy sector. For instance, the government support about the distributed solar PV within the country. The generation and distributed method can be classified into rooftop solar PV and groundmounted solar PV. The former is more suitable for households in the residential sector and the latter for larger on-grid utility-scale solar PV, e.g., IPP projects (IESR, 2019), with planned solar PV on-grid projects in Aceh and East Kalimantan. While there are several barriers in its development, such as local content requirements, land acquisition, unbalanced risk allocation and unattractive tariff and BOOT scheme, among other things (IESR, 2019), the key barrier in capturing the solar PV potential is that Indonesia lags other ASEAN countries in project development competencies and technology manufacturing (Asian Development Bank, 2020). At the very least, this can be addressed through knowledge transfer by capable investors. Despite the challenges, potential markets are abundant, including IPP projects, rural electrification, SOEs partnerships, mandatory RUEN requirements and utility-scale solar power plants.

\section{b. Hydroelectricity}

Hydroelectricity development in Indonesia is one of the top priorities of the government in NRE. It is seen as the most viable, consistent and sustainable source of power in reaching the country's $23 \%$ NRE target (Asian Development Bank, 2020). In addition, it is considered the most economical option for addressing the problem of rural electrification in developing countries (Erinofiardi et al., 2017). As of 2019, Indonesia has installed approximately 5.8 GW, eight percent out of its $94 \mathrm{GW}$ hydropower potential (Asian Development Bank, 2020). Hydropower plants' scales are further classified into pico, micro, mini, small and largely based on their power production capacity (Erinofiardi et al., 2017). However, the pursuit of hydropower potential is facing several constraints, specifically relating to socioenvironmental issues caused by large-scale hydropower development, e.g., flooding, environmental degradations and the threat to saltwater and freshwater ecosystems. In addition, the land procurement process tends to be lengthy, which may cause delays and financing problems (Asian Development Bank, 2020; Erinofiardi et al., 2017). To maximize the potential and accommodate those challenges, to develop and build hydro and mini-hydro power plant, the amount of expected investment was USD 36,4 billion to reach $21 \mathrm{GW}$ capacity in 2025 (IESR, 2019). The amount of investment itself displayed in investment projection of Indonesia electricity sector development stated by IESR in 2019, as follows in Table 2. 
Table 2. Investment projection of electricity sector development (IESR, 2019).

\begin{tabular}{|c|c|c|c|c|c|}
\hline Infrastructure & $\begin{array}{l}\text { Energy } \\
\text { Type }\end{array}$ & $\begin{array}{c}\text { Capacity } \\
\text { Target } 2025 \\
\text { (GW) }\end{array}$ & $\begin{array}{l}\text { Capacity Target } \\
2025 \text { (billion } \\
\text { USD) }\end{array}$ & $\begin{array}{l}\text { Capacity } \\
\text { Target } 2050 \\
\text { (GW) }\end{array}$ & $\begin{array}{c}\text { Capacity } \\
\text { Target 2050 } \\
\text { (billion USD) }\end{array}$ \\
\hline \multirow{7}{*}{$\begin{array}{l}\text { Renewable } \\
\text { Energy Power } \\
\text { Plant }\end{array}$} & Solar & 6.5 & 5.4 & 45 & 28.7 \\
\hline & Wind & 1.8 & 2.8 & 28 & 38.3 \\
\hline & Geothermal & 7.2 & 19.2 & 17.5 & 52.9 \\
\hline & Biomass & 5.5 & 6.7 & 26 & 1.0 \\
\hline & Mini Hydro & 3 & 8.1 & 7 & 20.6 \\
\hline & Hydro & 18 & 28.3 & 38 & 72.4 \\
\hline & Others & 3.1 & 2.2 & 3.1 & 12.6 \\
\hline \multicolumn{2}{|c|}{ Total } & 45.2 & 72.5 & 167.6 & 255.9 \\
\hline
\end{tabular}

On the other hand, the government has been attempting to address the above issues by easing the development process in forest areas through several regulations. The most viable form of investment would pico to small hydropower due to a large body of water as a source. Smaller-scale projects are considered less risky and will not take as much time to execute. Provinces with the most potential are West Sumatera, Bengkulu and NTT (Erinofiardi et al., 2017), where players such as MedcoEnergi have started development.

\section{c. Biomass}

Indonesia's government considers the domestic cultivation of biomass and its uses as critical in pursuing the $23 \%$ renewable target. The target set is mainly due to the richness of biomass sources in the nation, producing up to 146 million tons per year (Asian Development Bank, 2020). The primary uses of biomass, i.e., biofuels, with a potential of 200,000 barrels per day, and bioenergy amounting to $33 \mathrm{GW}$. Indonesia has installed five percent, approximately $1.7 \mathrm{GW}$ in total, with the top potential market for biomass power generation as cited in Dani and Wibawa (2018): Sumatera, Java and Kalimantan. According to Mahidin et al. (2020), the cost of biomass investment is around $900 \mathrm{USD} / \mathrm{kW}$ to 1,400 $\mathrm{USD} / \mathrm{kW}$, and the energy cost is Rp75/kW-Rp250/kW.

Moreover, biomass can be derived from various agricultural and forestry products, e.g. waste, palm oil, byproducts, bamboo, rubber and more (Mahidin et al., 2020). The relationship between biomass and the size of the palm oil industry in Indonesia is certainly to be highlighted. Despite the constraints of socioeconomic and environmental issues caused by the industry, the government has provided increasing support through the domestic use of biofuels requirements and subsidies, as elaborated in Dani and Wibawa (2018). In addition, the government announced that a 30\% blend of biofuel (B30) is compulsory for all fuel sources in hopes of supporting the market starting from 2020 (Asian Development Bank, 2020). Furthermore, the waste-to-energy subsector also shows potential as Indonesia is heavily populated, thus producing substantial city and municipal waste. This potential is supported by the government's plan to develop three waste-to-energy plants in Java and Banten.

\section{d. Geothermal}

Studies suggested that Indonesia has the greatest potential in geothermal energy at approximately 28.6 $\mathrm{GW}$, which accounts for $40 \%$ of the global potential, with Sumatra and Java topping the rank (Yudha et al., 2020). Geothermal energy is also a consistent solution in providing electricity as it is not affected by weather conditions. It is also a priority in RUEN and RUPTL to increase the capacity by $7.2 \mathrm{GW}$ by 2025. However, the utilization of geothermal in Indonesia was only $3.77 \%$ of the total energy utilization or approximately $2,130.6 \mathrm{MW}$ out of $56,509.53 \mathrm{MW}$, which is very low compared to a fellow ASEAN member, the Philippines, $44.5 \%$ geothermal usage rate (Yudha et al., 2021). The slow development of the sector mainly relates to the small market for the resource and the costly nature of resource exploration and commercialization. In addition, management challenges also exist since the sector is 
relatively untapped. The transition from fossil fuel economy to geothermal brings forward the knowledge transferability problem, which is expected to be refined and utilized in the geothermal sector in the near future. Another challenge is the high project development risk related to the inability to quantify resource potential before initiation. The government addressed these challenges by dedicating programs via the Infrastructure Financing for Geothermal Sector with several fiscal incentives such as tax deduction possibilities for developers. The sector is implementing a new cost-efficient risk-sharing mechanism, funded by the World Bank and the Green Climate Fund, to mitigate said resource risk for both public and private sector enterprises. Currently, the sector's key players are Star Energy Group (SEG), Pertamina Geothermal Energy (PGE), the Sarulla Consortium and Geo Dipa Energy (GDE) (Wilson, 2021).

\section{e. Wave and Tidal}

The wave and tidal energy sector focus on methods of harnessing energy from the ocean's elements. Wave energy relies on ocean waves to produce electricity, while tidal energy depends on low and high tides. Aside from the two, there are also salinity gradient energy and ocean thermal energy conversion (OTEC) (Yudha et al., 2021). According to the Indonesian Ocean Energy Association (cited in Yudha et al., 2021), as the world's largest archipelago, Indonesia has the largest potential in ocean energy of roughly $92.2 \mathrm{GW}$. However, as of 2020, ocean energy is still in its research and development phase and has yet to reach its commercial feasibility. The large investment cost relative to its projected profit has been the main reason for the lag behind the development. This lag is due to the need for adequate infrastructure and some equipment components that are still imported, in addition to the limited human and budgetary resources in the management (Sugianto et al., 2017). These factors serve as a barrier to entry for potential investors. On the other hand, several straits in Indonesia are considered potential sites for ocean energy exploitation, namely the Riau, Sunda and Lombok strait. However, the latest research indicates that data on the hydrodynamics of these sites requires a more accurate assessment of their potential (Mukhlis et al., 2017).

\subsection{Remarks}

To summarize, the Indonesian renewable energy sector is filled with lucrative investment opportunities in addition to the abundant supply of resources and more than adequate demand. The government has also shown considerable interest through reforms and incentives in supporting the growth of the sector. From the discussion, the key sub-sectors to be highlighted are hydropower, biomass and solar photovoltaic due to their potential demand and project feasibility. The geothermal and ocean energy sector is not to be dismissed as they show promising potential despite the lack of market and lack of knowledge respectively.

In order to achieve this first it should have to have its own uniqueness and pull factors that differentiate themselves from the conventional energy infrastructure. Based on the literature synthesis, we can conclude that there are three major variables influencing it: policy reformation, human capital development and empowered communities. All of these factors will lead into energy sector attractiveness, which in the end will attract the private sectors to place their investment in the renewable energy infrastructure.

\section{Future Studies}

After conducting a synthetic literature review and proposing the conceptual framework model that might affect private investment in Indonesia's renewable energy sector, the authors recommend that all stakeholders consider those their factors in developing renewable energy in Indonesia and encourage the private sector to invest and help the acceleration based on provided analysis on investment opportunities. As mentioned earlier within this current study, future studies are recommended to utilize the conceptual framework the baseline and execute it with more advanced statistical analysis. Therefore, both qualitative and quantitative approaches are expected to be performed within future studies. 


\section{References}

Agarwal, R., Agarwal, V., Hansmann, T., Lath, V., Tee Tan, K., \& Yi, Z. (2020). Ten ways to boost Indonesia's energy sector in a post-pandemic world. McKinsey. https://www.mckinsey.com/industries/oil-and-gas/our-insights/ten-ways-to-boost-indonesiasenergy-sector-in-a-postpandemic-world

Arafah, W., Nugroho, L., Takaya, R., \& Soekapdjo, S. (2018). Marketing strategy for renewable energy development in Indonesia context today. International Journal of Energy Economics and Policy, $8(5), 181-186$.

Ardiansyah, F., Drahos, P., \& Gunningham, N. (2012). An environmental perspective on energy development in Indonesia. Springer. https://openresearchrepository.anu.edu.au/handle/1885/20236

Asian Development Bank. (2020). Indonesia energy sector assessment, strategy, and road map update (Indonesia). Asian Development Bank. https://www.adb.org/documents/indonesiaenergy-assessment-strategy-road-map-update

Asian Development Bank. (2021). Asian Development Outlook (ADO) 2021 supplement: Renewed outbreaks and divergent recoveries (Issue July 2021). Asian Development Bank. https://www.adb.org/publications/ado-supplement-july-2021

Bappenas. (2012). Kementerian PPN/Bappenas-Policy paper of harmonizing National Energy Policy (KEN) with General Plan on National Energy (RUEN) and General Plan on Regional Energy (RUED). https://www.bappenas.go.id/id/profil-bappenas/unit-kerja/deputi-bidang-sumber-dayaalam-dan-lingkungan-hidup/direktorat-sumber-daya-energi-mineral-dan-

pertambangan/contents-direktorat-sumber-daya-energi-mineral-dan-pertambangan/3751-policypaper-keselarasan-kebijakan-energi-nasional-ken-dengan-rencana-umum-energi-nasional-ruendan-rencana-umum-energi-daerah-rued/

Dani, S., \& Wibawa, A. (2018). Challenges and policy for biomass energy in Indonesia. 15(5), 7.

Day, J. W., D’Elia, C. F., Wiegman, A. R. H., Rutherford, J. S., Hall, C. A. S., Lane, R. R., \& Dismukes, D. E. (2018). The energy pillars of society: Perverse interactions of human resource use, the economy, and environmental degradation. Biophysical Economics and Resource Quality, 3(1), 2. https://doi.org/10.1007/s41247-018-0035-6

Desfiandi, A., Singagerda, F. S., \& Sanusi, A. (2019). Building an energy consumption model and sustainable economic growth in emerging countries. International Journal of Energy Economics and Policy, 9(2), 51-66.

Dias, R. A., Mattos, C. R., \& P. Balestieri, J. A. (2006). The limits of human development and the use of energy and natural resources. Energy Policy, 34(9), 1026-1031. https://doi.org/10.1016/j.enpol.2004.09.008

DJEBTKE. (2017). Indonesian renewable energy policy and investment opportunities. Asia Clean Energy Forum 2017.

Dutu, R. (2016). Challenges and policies in Indonesia's energy sector. Energy Policy, 98, 513-519. https://doi.org/10.1016/j.enpol.2016.09.009

Erdin, C., \& Ozkaya, G. (2019). Turkey's 2023 energy strategies and investment opportunities for renewable energy sources: Site selection based on ELECTRE. Sustainability, 11(7), 2136. https://doi.org/10.3390/su11072136

Erdiwansyah, Mahidin, Mamat, R., Sani, M. S. M., Khoerunnisa, F., \& Kadarohman, A. (2019). Target and demand for renewable energy across 10 ASEAN countries by 2040. The Electricity Journal, 32(10), 106670. https://doi.org/10.1016/j.tej.2019.106670

Erinofiardi, Gokhale, P., Date, A., Akbarzadeh, A., Bismantolo, P., Suryono, A. F., Mainil, A. K., \& Nuramal, A. (2017). A review on micro hydropower in Indonesia. Energy Procedia, 110, 316321. https://doi.org/10.1016/j.egypro.2017.03.146

Ghosh, S. (2007). Investment opportunities in the Indian energy sector. International Journal of Indian Culture and Business Management, 1(1-2), 64-82. https://doi.org/10.1504/IJICBM.2007.014471

Guerreiro, S., \& Botetzagias, I. (2018). Empowering communities - the role of intermediary organizations in community renewable energy projects in Indonesia. Local Environment, 23(2), 158-177. https://doi.org/10.1080/13549839.2017.1394830 
Hariadi, T. K., Derks, M., Jamal, A., \& Riyadi, S. (2018). Renewable energy investment for middle and upper-class housing sector in Indonesia: Investigating the scope for a change in policy. Journal of Electrical Technology UMY, 2(1), 12-18. https://doi.org/10.18196/jet.2129

Hesty, N. W., Cendrawati, D. G., Nepal, R., \& Al Irsyad, M. I. al. (2021). Energy potential assessments and investment opportunities for wind energy in Indonesia (SSRN Scholarly Paper ID 3811064). Social Science Research Network. https://papers.ssrn.com/abstract=3811064

Hidayatno, A., Destyanto, A. R., \& Handoyo, B. A. (2019). A conceptualization of renewable energypowered industrial cluster development in Indonesia. Energy Procedia, 156, 7-12. https://doi.org/10.1016/j.egypro.2018.11.074

Institute for Essential Services Reform. (2019). Indonesia clean energy outlook 2020. IESR. https://iesr.or.id/en/pustaka/iceo2020

International Energy Agency. (2018). Energy policy review of Indonesia. OECD Publisher.

Kejora Capital. (2021). Fund teaser: Kejora future energy fund - An energy sector focused vc fund. Kejora Capital.

Kennedy, S. F. (2018). Indonesia's energy transition and its contradictions: Emerging geographies of energy and finance. Energy Research \& Social Science, 41, 230-237. https://doi.org/10.1016/j.erss.2018.04.023

Kim, K., Park, H., \& Kim, H. (2017). Real options analysis for renewable energy investment decisions in developing countries. Renewable and Sustainable Energy Reviews, 75, 918-926. https://doi.org/10.1016/j.rser.2016.11.073

Kumar. J., C. R., \& Majid, M. A. (2020). Renewable energy for sustainable development in India: Current status, future prospects, challenges, employment, and investment opportunities. Energy, Sustainability and Society, 10(1), 2. https://doi.org/10.1186/s13705-019-0232-1

Lohtaja, K. (2020). Assessment of climate change risks and impacts in investment opportunities [Fi=Ylempi AMK-opinnäytetyö|sv=Högre $\quad$ YH-examensarbete|en=Master's thesis|]. http://www.theseus.fi/handle/10024/349374

Mahidin, Erdiwansyah, Zaki, M., Hamdani, Muhibbuddin, Hisbullah, Mamat, R., \& Susanto, H. (2020). Potential and utilization of Biomass for heat energy in Indonesia: A review. Undefined. https://www.semanticscholar.org/paper/Potential-And-Utilization-Of-Biomass-For-Heat-In-AMahidin-Erdiwansyah/e180b00a25bd4243864453de87979050bee3d26e

Mahmood, N., Wang, Z., \& Hassan, S. T. (2019). Renewable energy, economic growth, human capital, and $\mathrm{CO} 2$ emission: An empirical analysis. Environmental Science and Pollution Research, 26(20), 20619-20630. https://doi.org/10.1007/s11356-019-05387-5

Marquardt, J. (2014). A struggle of multi-level governance: Promoting renewable energy in Indonesia. Energy Procedia, 58, 87-94. https://doi.org/10.1016/j.egypro.2014.10.413

Masini, A., \& Menichetti, E. (2013). Investment decisions in the renewable energy sector: An analysis of non-financial drivers. Technological Forecasting and Social Change, 80(3), 510-524. https://doi.org/10.1016/j.techfore.2012.08.003

Maulidia, M., Dargusch, P., Ashworth, P., \& Ardiansyah, F. (2019). Rethinking renewable energy targets and electricity sector reform in Indonesia: A private sector perspective. Renewable and Sustainable Energy Reviews, 101, 231-247. https://doi.org/10.1016/j.rser.2018.11.005

Mukhlis, A., Firdaus, A., Houlsby, G., Aa, T., \& Adcock. (2017). Opportunities for tidal stream energy in Indonesian waters.

Mustikaningsih, D., Cahyandito, M. F., Kaltum, U., \& Sarjana, S. (2019). Building business performance through partnership strategy model: Evidence from renewable energy industry in Indonesia. International Journal of Energy Economics and Policy, 9(5), 297-307.

Nakhooda, S. (2014). Getting it together: Institutional arrangements for coordination and stakeholder engagement in climate finance. Odi.Org. https://odi.org/en/publications/getting-it-togetherinstitutional-arrangements-for-coordination-and-stakeholder-engagement-in-climate-finance/

Naser, H. (2014). Oil market, nuclear energy consumption and economic growth: Evidence from emerging economies. International Journal of Energy Economics and Policy, 4(2), 288-296.

Nasirov, S., Silva, C., \& Agostini, C. A. (2016). Assessment of barriers and opportunities for renewable energy development in Chile. Energy Sources, Part B: Economics, Planning, and Policy, 11(2), 150-156. https://doi.org/10.1080/15567249.2015.1062820 
Nugroho, H., Fei-Lu, S., \& Firmansyah. (2017). Developing renewable energy in developing countries: A lesson from Indonesia. Energy Sources, Part B: Economics, Planning, and Policy, 12(4), 318 325. https://doi.org/10.1080/15567249.2015.1072599

O'neill, A. (2021). Indonesia-Gross domestic product (GDP) growth rate 2026. Statista. https://www.statista.com/statistics/320068/gross-domestic-product-gdp-growth-rate-inindonesia/

Palanichamy, C., Sundar Babu, N., \& Nadarajan, C. (2004). Renewable energy investment opportunities in Mauritius-An investor's perspective. Renewable Energy, 29(5), 703-716. https://doi.org/10.1016/j.renene.2003.09.014

Pusdatin. (2016). Kementerian ESDM RI - Publication-Handbook of Energy \& Economic Statistics of Indonesia (HEESI). https://www.esdm.go.id/en/publication/handbook-of-energy-economicstatistics-of-indonesia-heesi

Putrasari, Y., Praptijanto, A., Santoso, W. B., \& Lim, O. (2016). Resources, policy, and research activities of biofuel in Indonesia: A review. Energy Reports, 2, 237-245. https://doi.org/10.1016/j.egyr.2016.08.005

Rehman, M. U., \& Vo, X. V. (2020). Do alternative energy markets provide optimal alternative investment opportunities? The North American Journal of Economics and Finance, 54, 101271. https://doi.org/10.1016/j.najef.2020.101271

Reyseliani, N., \& Purwanto, W. W. (2021). Pathway towards 100\% renewable energy in Indonesia power system by 2050. Renewable Energy, 176, 305-321. https://doi.org/10.1016/j.renene.2021.05.118

Schmidt, T. S., Blum, N. U., \& Sryantoro Wakeling, R. (2013). Attracting private investments into rural electrification-A case study on renewable energy-based village grids in Indonesia. Energy for Sustainable Development, 17(6), 581-595. https://doi.org/10.1016/j.esd.2013.10.001

Setiartiti, L. (2018). Renewable energy utilizing for clean energy development. International Journal of Energy Economics and Policy, 8(1), 212-219.

Setyawan, D. (2014). Assessing the current Indonesia's electricity market arrangements and the opportunities to reform. International Journal of Renewable Energy Development, 3(1), 55-64.

Sharvini, S. R., Noor, Z. Z., Chong, C. S., Stringer, L. C., \& Yusuf, R. O. (2018). Energy consumption trends and their linkages with renewable energy policies in East and Southeast Asian countries: Challenges and opportunities. Sustainable Environment Research, 28(6), 257-266. https://doi.org/10.1016/j.serj.2018.08.006

Singh, A. (2012). Renewable energy in the pacific island countries: Resources, policies and issues. Management of Environmental Quality: An International Journal, 23(3), 254-263. https://doi.org/10.1108/14777831211217459

Sovacool, B. K., \& Mukherjee, I. (2011). Conceptualizing and measuring energy security: A synthesized approach. Energy, 36(8), 5343-5355. https://doi.org/10.1016/j.energy.2011.06.043

Sugianto, D., Kunarso, Helmi, M., Alifdini, I., Maslukah, L., Saputro, S., Yusuf, M., \& Endrawati, H. (2017). Wave energy reviews in Indonesia. International Journal of Mechanical Engineering and Technology (IJMET), 8, 448-459.

Sugiarto, W. (2021). Positive outlook for Indonesia's geothermal sector. PEFINDO.

Tasri, A., \& Susilawati, A. (2014). Selection among renewable energy alternatives based on a fuzzy analytic hierarchy process in Indonesia. Sustainable Energy Technologies and Assessments, 7, 34-44. https://doi.org/10.1016/j.seta.2014.02.008

Tumiwa, F., \& Rambitan, I. (2013). Scaling up renewable energy investments: Lessons from the best practices model in Indonesia. Clean Energy Solutions Center. https://www.cleanenergysolutions.org/es/resources/scaling-renewable-energy-investmentslessons-best-practices-model-indonesia

Udin, U. (2020). Renewable energy and human resource development: Challenges and opportunities in Indonesia. International Journal of Energy Economics and Policy, 10(2), 233-237.

WAVTEQ. (2017). Investment opportunities in Indonesia: Renewable energy. Canada-Indonesia Trade and Private Sector Assistance Project.

Winarno, O. T., Alwendra, Y., \& Mujiyanto, S. (2016). Policies and strategies for renewable energy development in Indonesia. 2016 IEEE International Conference on Renewable Energy Research and Applications (ICRERA), 270-272. https://doi.org/10.1109/ICRERA.2016.7884550 
Wüstenhagen, R., \& Menichetti, E. (2012). Strategic choices for renewable energy investment: Conceptual framework and opportunities for further research. Energy Policy, 40, 1-10. https://doi.org/10.1016/j.enpol.2011.06.050

Yudha, S. W., \& Tjahjono, B. (2019). Stakeholder mapping and analysis of the renewable energy industry in Indonesia. Energies, 12(4), 602. https://doi.org/10.3390/en12040602

Yudha, S. W., Tjahjono, B., \& Longhurst, P. (2020). Stakeholders' recount on the dynamics of Indonesia's renewable energy sector. https://doi.org/10.20944/preprints202010.0083.v1 